\title{
KEBIJAKAN HUKUM PIDANA MEMPERTAHANKAN JENIS PIDANA MATI \\ (STUDI KASUS PEMBUNUHAN BERENCANA DISERTAI MUTILASI KORBAN)
}

Oleh :

\section{A.A. Sagung Mas Yudiantari Darmadi ${ }^{1}$}

\begin{abstract}
The research was policy of criminal law maintains kind of death penalty (the case study of plan murder while mutilates the victim), aims to describe and analyze the existence of the death penalty to the crime of plan murder. In addition, this study also aims to determine policies of criminal law related to death penalty for the crime of plan murder accompanied by mutilation as an aggravating. The method used in this research was conducted normatively by reviewing the primary and secondary which was collected based on collecting method of normative law and for the technique of collecting its legal entity were used documenter technique i.e the technique to analyze and collect on various documents that already exists by applying some kind of approach, namely, the approach of legislation, and analytical approaches. The analysis of research was presented in form of descriptive-analytical, systematic, constructive and argumentative.

The death penalty against the crime of murder is still maintained and in force today in Indonesia, as contained in the provisions of Article 340 of the Criminal Code. Capital punishment are recognized in the criminal offense of premeditated murder, but the death penalty was alternatifed with other criminal types namely life imprisonment and a maximum of 20 years. Death penalty imposed in the case of things that are burdensome. By it did not published things that incriminate a crime in the Criminal Code, the judge only include things that are burdensome and ease generally. This certainly can not be released that the provisions of Article 197 paragraph (1) Criminal Code incriminating things was imperatively. Regarding the criminal law policy relating to the death penalty for the crime of murder was listed in Article 581 of the Criminal Code. In this case, the RUU KUHP did not include the Criminal Code specifically mutilation as a criminal aggravating reasons, however when seen from the provisions of Article 55 paragraph (1), the mutilation may be a motive and purpose of committing a crime (letter b); how committed the crime (letter e); as well as the attitudes and actions of after committing a crime (letter $\mathrm{f}$ ).
\end{abstract}

Keywords : Criminal Law, Death Penalty, Policy,

\section{Pendahuluan}

\subsection{Latar Belakang}

Negara Indonesia tetap mengakui dan mempertahankan pidana mati untuk menjerat orang yang melakukan kejahatan.

Mahasiswa Magister Ilmu Hukum Universitas Udayana, Denpasar, Bali. Alamat J1. Raya Kuta 100AB Kuta Badung.
Hal ini sesuai dengan ketentuan Pidana, yang memuat penjatuhan sanksi.

Berbagai macam tindak pidana telah termuat ketentuan mengenai sanksi, seperti halnya terhadap kasus kejahatan terhadap keamanan negara, sesuai dengan kentuan hukum pidana positif Pasal 104, Pasal 111 ayat (2), dan sebagainya; pencurian dengan 
kekerasan disertai dengan pemberatan dalam Pasal 365 ayat (4); pembunuhan berencana sesuai dengan Pasal 340; pembajakan laut, pantai, dan sungai tercantum dalam Pasal 444 serta sebagainya. Tidak hanya di dalam KUHP saja, keberadaan pidana mencabut nyawa seseorang juga dapat ditemui dalam rumusan perundang-undangan di luar itu, seperti Undang-Undang (UU) Narkotika yang tercantum dalam Pasal 113 ayat (2), 114 ayat (2), 116 ayat (2), 118 ayat (2), 119 ayat (2), 121 ayat (2), dan 133 ayat (1); UU Terorisme yang tercantum dalam ketentuan Pasal 14; UU Korupsi sesuai dengan Pasal 2 ayat (2), dan sebagainya.

Sehingga dengan menempatkan pidana yang tergolong berat sebagai salah satu jenis pidana yang yang ada dalam atau pun di luar KUHP, maka tidak menutup kemungkinan hakim yang ditunjuk menangani suatu perkara pidana yang diatur dengan hukuman mati, bisa menjatuhkan vonis tersebut pada pelaku kejahatan tertentu (tergolong berat).

Seiring dengan perkembangan zaman serta semakin kompleksnya permasalahanpermasalahan yang timbul dalam masyarakat disuatu Negara tidak heran jika hukum yang ada dalam suatu Negara mengalami suatu perubahan yang selalu berusaha mewujudkan suatu tujuan hukum yang dicita-citakan. Berkenaan dengan jenis hukum yang berlaku disuatu Negara, terutama mengenai masalah pidana pencabutan nyawa tentu di setiap Negara mempunyai pandangan yang berbeda-beda tentang pemberlakuannya.

Indonesia yang akan melakukan pembaharuan hukum pidana, secara pasti belumbisa melepaskan diri daripermasalahan pidana pencabut kemerdekaan seseorang.
Adanya pro dan kontra terhadap pidana yang tergolong berat ini dilatarbelakangi oleh berbagai macam alasan, misalnya pihak yang pro terhadap beralasan bahwa hal ini tetap diperlukan untuk pencegahan dan perlindungan masyarakat dari tindakan kejahatan, termasuk pula sebagai suatu upaya untuk memberikan efek jera kepada penjahat. Pihak ini didukung oleh putusan Mahkamah Konstitusi yang menyatakan memutuskan pidana mati tidak melanggar landasar dasar negara Indonesia. Memang sebenarnya putusan tersebut hanya sebatas dalam judicial review tindak pidana narkotika, tetapi hal itu dianggap mewakili aspirasi masyarakat luas bahwa penggunaan pidana mati merupakan sanksi yang dapat dijatuhkan pada mereka yang melanggar hukum pidana. Selanjutnya, bagi pihak yang kontra menunjukkan adanya ketidakadilan terhadap kehidupan manusia, oleh karena manusia mempunyai hak hidup yang harus dilindungi sehingga hanya Tuhan yang bisa mencabutnya.

Berbicara tentang Rancangan KUHP baru, dalam Pasal 66 Rancangan KUHP nasional tahun 2013, bahwa pidana mati tidaklah diatur sebagai pidana pokok akan tetapi sebagai pidana alternatif. Hal ini menyebabkan penjatuhan pidana yang berat ini masih sangat diperlukan sebagai suatu bagian dari adanya sanksi pidana yang dapat dijatuhkan oleh hakim.

Penjatuhan sanksi pokok berupa pencabutan nyawa bagi yang melakukan tindak pidana, merupakan masalah yang rumit bagi masyarakat Indonesia, terutama bagi aparat negara untuk menegakkan keadilan yang berprikemanusiaan. 
Kejahatan yang ditujukan bagi nyawa orang lain ialah bentuk perbuatan dengan menyerang nyawa seseorang. ${ }^{2}$ Salah satu kejahatan terhadap nyawa seseorang adalah dengan sengaja mencabut nyawa seseorang yang menurut kodifikasi hukum pidana warisan Belanda yang masih diberlakukan saat ini disebut pembunuhan. Untuk menghilangkan hidup seseorang, harus melakukan beberapa langkah yang dapat mengakibatkan matinya orang dengan catatan bahwa opzet dari pelakunya itu harus ditujukan pada akibat berupa meninggalnya orang lain tersebut. ${ }^{3}$

Perkembangan yang sangat signifikan dengan diiringi model dan gaya pembunuhan yang terjadi di Indonesia saat ini semakin hari semakin mengalami pembunuhan yang beraneka ragam, dari cara yang mudah hingga dengan cara terbilang sadis dan kejam. Tindakan membunuh dengan rencana terlebih dahulu disertai dengan mutilasi merupakan suatu motif pembunuhan yang dilakukan secara sadis dan kejam dan memang motif yang terjadi di lapangan ini menyatakan bahwa perbuatan tersebut dilakukan untuk menghilangkan jejak perbuatan yang telah dilakukan oleh pelaku maupun bisa saja pelaku sendiri mengalami kelainan psikologis yang menyebabkan pelaku melakukan tindakan mutilasi terhadap korbannya. Sungguh sangat ironis memang jika ternyata motif-motif dari pembunuhan disertai mutilasi tersebut terkadang hanya

Adam Chazawi, 2007, Kejahatan Terhadap Tubuh dan Nyawa, PT. Raja Grafindo Persada, Jakarta, hlm.55.

Lamintang, P.A.F, dan Lamintang, Theo, 2013, DelikDelik Khusus Kejahatan Terhadap Nyawa, Tubuh, dan Kesehatan, Edisi Kedua, Sinar Grafika, Jakarta, hlm.1. dilatarbelakangi oleh persoalan-persoalan yang bisa dianggap hal sepele, seperti saling mengejek, rasa dendam, sakit hati terhadap korban, dan persoalan-persoalan lain sebagainya yang sesungguhnya dapat diatasi dengan gaya berpikir dewasa dan jernih.

Penjatuhan pidana mati tentunya tidak terlepas dari berbagai pertimbangan yang harus dilakukan Hakim. Selain pertimbangan-pertimbangan tersebut, perlu juga dipertimbangkan hakikat dan keadaankeadaan yang menyertai suatu kejahatan, riwayat dan pelaku tindak pidana dan lembaga-lembaga serta sumber-sumber yang ada dalam masyarakat. Dasar pertimbangan Hakim tersebut merupakan landasan atau kunci pokok yang akan menghasilkan putusan terhadap semua jenis pemidanaan termasuk pula di dalamnya putusan pidana mati. Walaupun memang secara tertulis dalam hukum pidana kita tidak pernah dijumpai aturan yang menggariskan suatu pedoman yang dipakai landasan oleh Hakim sebagai dasar pertimbangan dalam penjatuhan pidana tersebut. Cenderung hal ini membawa konsekuensi karena tidak ada landasan berpijak bagi Hakim sebagai pedoman di dalam memberikan dasar pertimbangan. Oleh karena itu, sering kali putusan dari Hakim banyak mengandung pro-kontra dari masyarakat, yang seolaholah kurang memberikan rasa kepastian hukum dan kurang mencerminkan wibawa hukum di mata masyarakat.

Jenis pidana terhadap tindak pidana pembunuhan berencana, perumusan ancaman pidananya dirumuskan secara alternatif. Penjatuhan berupa sanksi mati dapat saja dijatuhkan dalam hal adanya pemberatan 
pidana. Namun, dalam hukum pidana positif (yang berlaku saat ini) belum dilengkapi dengan pedoman pemidanaan mengenai hal-hal yang memberatkan maupun yang meringankan pidana. Padahal menurut Kitab Undang-Undang Hukum Acara Pidana, tidak dicantumkannya hal-hal tersebut konsekuensinya adalah batalnya putusan hakim, sesuai dengan aturan Pasal 197 ayat (1) KUHAP.

Meskipun mengancamkan batalnya putusan ataupun kelalaian mencantumkan alasan memberatkan dan meringankan terdakwa, akan tetapi apabila diperhatikan seringkali hal-hal yang dijadikan alasan memberatkan dan meringankan dalam suatu putusan sangat umum sifatnya. Terhadap alasan yang memberatkan seperti perbuatan terdakwa meresahkan masyarakat, menimbulkan kerugian bagi korban, menimbulkan kesedihan yang mendalam bagi korban, dan sebagainya, sedangkan untuk hal yang meringankan seperti mengakui dan menyesali, terdakwa sudah tua, terdakwa masih muda dan mempunyai tanggungan keluarga, serta sopan di persidangan. Beberapa putusan juga sering ditemui beberapa alasan yang memberatkan berupa terdakwa tidak mengakui perbuatannya dan berbelit-belit di persidangan.

Selain itu, melihat daripada ketentuan Pasal 14 ayat (2) UU Kekuasaan Kehakiman, hakim berkewajiban untuk memberikan dasar untuk mempertimbangkan atau argumentasi secara tulisan dalam kasus yang ditangani. Dalam setiap putusan yang dihasilkan lembaga pengadilan, senantiasa terlihat pula dalam putusan tersebut hal-hal yang memberatkan dan meringankan pidana.
Pembunuhan berencana yang disertai dengan mutilasi sebagai suatu hal yang memberatkan dapat dijatuhi putusan pidana mati, hal ini dikarenakan dalam pembunuhan bukan merupakan suatu delik yang dikualifikasi sebagai dasar pemberat.

Hal inilah yang menandakan adanya kekosongan norma terhadap pedoman pemidanaan hakim yang memberikan dasardasar pertimbangan terhadap putusannya, baik itu dalam pemberatan maupun peringanan dalam putusan dan inipun menjadi suatu permasalahan hukum, karena tiadanya kepastian hukum dan keadilan bagi masyarakat.

Berdasarkan uraian latar belakang tersebut diatas, telah mendorong penulis untuk mengangkat dan mengkajinya lebih dalam dengan mewujudkannya ke dalam suatu penelitian yang berjudul "Kebijakan Hukum Pidana Mempertahankan Jenis Pidana Mati (Studi Kasus Pembunuhan Berencana Disertai Mutilasi Korban)".

\subsection{Rumusan Masalah}

1. Bagaimanakah eksistensi pidana mati terhadap tindak pidana pembunuhan berencana?

2. Bagaimana kebijakan dalam hukum pidana terkait pidana mati untuk tindak pidana pembunuhan berencana disertai mutilasi sebagai hal yang memberatkan?

\subsection{Tujuan Penelitian}

Menganalisis mengenai eksistensi pidana mati terhadap tindak pidana pembunuhan berencana. Selanjutnya untuk mendeskripsi mengenai kebijakan hukum pidana terkait pidana mati terhadap tindak pidana pembunuhan berencana disertai mutilasi sebagai hal yang memberatkan. 


\section{Metode Penelitian}

Penelitian hukum yang dipergunakan ialah normatif. Menggunakan metode ini karena mempelajari bahan-bahan hukum sebagai acuan dalam penyelesaian masalah penelitian ini. Hal ini pula beranjak juga dari belum adanya norma hukum yang berkaitan dengan permasalahan penelitian. Terhadap permasalahan yang dikaji, maka pendekatan masalah yang digunakan adalah perundangundangan. Selanjutnya, pendekatan analitis adalah seorang peneliti akan mengkaji secara mendalam atas tulisan dalam sebuah putusan-putusan pengadilan dan juga peraturan perundang-undangan. Para sarjana berpendapat, bahwa kajian hukum normatif mengandalkan pada penggunaan bahan hukum primer, bahan hukum sekunder, dan bahan hukum tersier. ${ }^{4}$

Penelitian hukum tersebut, memiliki kekuatan mengikat ke dalam. ${ }^{5}$ Bahan hukum primer bersifat autoritatif, dalam artian mempunyai otoritas. ${ }^{6}$ Bahan hukum primer terdiri dari peraturan perundangundangan, catatan resmi ataupun risalah putusan hakim. ${ }^{7}$ Bahan hukum primer yang dipergunakan dalam penelitian ini meliputi :UUD NRI Tahun 1945; KUHP; KUHAP; UU Pemasyarakatan; UU HAM; DUHAM. Bahan hukum sekunder diambil atau diperoleh dari text book, artikel, hasil penelitian terkait dengan penulisan ini,

Soerjono Soekanto \& Sri Mamudji, 2006, Penelitian Hukum Normatif Suatu Tinjauan Singkat, Raja Grafindo Persada, Jakarta, hlm.13.-

5 Bambang Sugono, 2006, Metodelogi Penelitian Hukum, PT. Raja Grafindo Persada, Jakarta hlm.13.

6 Amiruddin dan H. Zainal Asikin, 2004, Pengantar Metode Penelitian Hukum, PT Raja Grafindo Persada, Jakarta, hlm.118.

Peter Mahmud Marzuki, 2006, Penelitian Hukum, Kencana, Jakarta, hlm.141. dan juga kamus hukum. Pengumpulan bahan hukum yang dipergunakan adalah dokumenter yakni untuk mengkaji serta mengumpulkan tentang berbagai dokumendokumen yang sudah ada. ${ }^{8}$ Selanjutnya, disajikan dalam bentuk deskriptif-analitis, evaluatif, sistematis, konstruktif dan argumentatif.

\section{Hasil dan Pembahasan}

\subsection{Pengaturan Pidana Mati Terhadap Tindak Pidana Pembunuhan Berencana Disertai Mutilasi}

Pengaturan pidana mati dalam hukum pidana positif Indonesia bermula pada jaman pemerintahan kolonial Belanda sejak tanggal 1 Januari 1918, yang mana diatur dalam wetbook van strafrecht voor nederlandsch inide dalam Buku I, Bab II tentang pokok-pokok pidana dalam Pasal 10 jo Pasal 11. Pidana mati tersebut dijatuhan terhadap jenis-jenis pelanggaran berat, akan tetapi sekarang di Belanda pidana mati telah dihapuskan sudah lama.

Pidana mati bagi kejahatan extra ordinary crime (teroris, pengedar narkoba, pembunuhan berencana dengan modus operandi yang sadis) sama sekali bukan dengan tujuan balas dendam seperti yang sering dituduhkan oleh kelompok yang kontra terhadap pidana mati melainkan berdasarkan keyakinan moral bahwa kejahatan yang mereka lakukan, secara moral adalah kejahatan yang sangat berat dan meresahkan serta melukai perasaan moral keadilan masyarakat.

Salim, 2013, Penerapan Teori Hukum Pada Penelitian Tesis dan Disertasi, Raja Grafindo Persada, Jakarta, hlm.19. 
Pidana pencabut nyawa sebagai salah satu pidana pokok di Indonesia merupakan suatu pidana yang paling kontroversial diantara pidana lainnya. Pidana mati mengalami suatu kontroversi terhadap hak hidup dalam konstitusi negara Indonesia maupun aspek pengaturan hukum internasional. Namun secara khusus, ICCPR sama sekali tidak melakukan suatu pelarangan tentang penjatuhan pidana mati akan tetapi untuk menerapkan hal tersebut terdapat batasan-batasan sesuai dengan aturan norma yang berlaku.

Adapun beberapa syarat-syarat yang harus dipenuhi jika pidana mati ini masih tetap dipertahankan, yakni :

a. Hanya dapat dijatuhkan apabila benarbenar kepentingan umum terancam.

b. Hakim benar-benar yakin akan kesalahan si terdakwa dapat dibuktikan selengkap-lengkapnya.

c. Diancamkan secara alternatif dengan jenis pidana lain, artinya tidak dijatuhkan semata-mata sehingga hakim dapat memilih yang menurut keyakinannya lebih sesuai dengan kesalahan si terdakwa. ${ }^{9}$

Pemidanaan memang mustahil menghapuskan kejahatan dari muka bumi, akan tetapi paling tidak pemidanaan menyebabkan the sense of justice of the victims menjadi terwujud. ${ }^{10}$ Terdapat tiga unsur yang harus diperhatikan dalam menegakkan hukum yakni kepastian hukum, keadilan dan kemanfaatan. Hukum ialah

Tolib Setiady, op.cit, hlm.85

10 Achmad Ali, 2010, Menguak Realitas Hukum : Rampai Kolom \& Artikel Pilihan Dalam Bidang Hukum, Prenada Media Group, Jakarta, hlm.36. untuk manusia, sehingga dalam penegakan hukum harus memberikan manfaat bagi masyarakat, adanya kepastian terhadap norma hukum yang ada untuk membuat tertib masyarakat, serta rasa keadilan yang begitu penting secara keseluruhan. ${ }^{11}$

Berbicara mengenai hukum khususnya mengenai hukum pidana sendiri, tentunya tidak terlepas dari berbagai macam jenis-jenis kejahatan maupun pelanggaranpelanggaran. Contoh kasus kejahatan yakni pembunuhan yang belakangan terjadi di Indonesia adalah dengan cara sadis salah satunya dilakukan dengan cara memutilasi bagian tubuh korban dengan tujuan untuk melenyapkan jejak korban setelah kejahatan nyawa itu dilakukan. Secara rasional, hal ini dilakukan dengan tujuan untuk menghilangkan tubuh korban sebagai barang bukti (mutilasi defensif). ${ }^{12}$

Pengaturan pidana mati terhadap tindak pidana pembunuhan berencana dilihat dari aspek peraturan perundang-undangan yang mengatur masalah HAM di Indonesia, mempunyai Legitimasi yang kuat. Legitimasi tersebut lebih diperkuat lagi dengan salah satu instrumen hukum penegakan HAM internasional, yaitu International Convenant on Civil and Political Right. Negara yang belum menghapuskan aturan tentang pidana mati, dimana putusan yang menjatuhkan hal itu hanya berlaku pada kejahatan yang tergolong serius sesuai dengan hukum

Rifkiyati Bachri, Pembunuhan Berencana dan Mutilasi(Kajian Putusan) No.1036 / PID /B / 2008/ PN.DPK, Jurnal Yudisial, Vol. 3, No. 2 Edisi Agustus 2010, Fakultas Hukum Universitas Pancasila, Jakarta, hlm.204.

12 Supardi Ramlan, 2001, Patofisiologi, Rineka Cipta, Bandung, hlm.35. 
positif serta tidak memiliki pertentangan dengan konvenan ini. Menurut kovenan ini jika suatu kejahatan diasumsikan sebagai kejahatan berat atau kejahatan serius maka, pidana mati terhadapnya dapat dibenarkan.

Sehingga, sampai kapanpun pidana mati akan tetap dibutuhkan terhadap pelakupelaku kejahatan berat yang secara langsung membahayakan nyawa sesama manusia, seperti pembunuhan dengan cara mutilasi yang tergolong sadis ini, tetapi bukan sekedar mengancamkan dalam undang-undang, melainkan benar-benar dalam realitasnya menjadi vonis hakim dan dieksekusi benar-benar. Pelaksanaan pidana mati perlu pembaharuan kembali, sebagaimana diketahui belum ada aturan yang jelas pula tentang berapa lama proses eksekusi mati terhadap si terpidana mati.

Betapa perlunya pidana mati ini dipertegas kembali oleh Immanuel Kant dalam "The Science Right", yang menyatakan bahwa: "if you slander another, you slander yourself; if you steal from another, you steal from yourself; if you strike another, you strike yourself; if you kill another, you kill yourself." ${ }^{13}$ Kalimat di atas yang dinyatakan oleh Immanuel Kant, menegaskan dukungannya terhadap pidana mati bagi pelaku kejahatan serius, baik yang memang secara nyata telah menghilangkan nyawa manusia, maupun yang dapat dianggap telah menghilangkan sejumlah nyawa manusia meskipun secara tidak langsung, sebagaimana yang menurut penulis sendiri termasuk didalamnya adalah pembunuhan berencana dengan modus sadis dan kejam (mutilasi).

\footnotetext{
Achmad Ali, op.cit, hlm.37.
}

\subsection{Kebijakan Hukum Pidana Menetapkan Pidana Mati Sebagai Salah Satu Jenis Pidana Dalam Perspektif Ius Constituendum.}

Masalah Pembaharuan hukum pidana meliputi pembaharuan materi, budaya, struktur, sistem politik, sosial, ekonomi serta etika hukum dan pendidikan ilmu hukum. ${ }^{14}$

Ketentuan terhadap pidana pencabutan nyawa dalam RUU KUHP mempunyai maksud tidak mempergunakan pidana perampasan nyawa sebagai hukuman mati, melainkan menaruh pidana ini kedalam pidana secara mengkhusus bersifat alternatif. Pertimbangan-pertimbangan yang nantinya dinyatakan oleh hakim dalam memvonis pidana pencabutan nyawa ditujukan terhadap sikap dan tindakan daripada perbuatan terdakwa maupun dampak yang terjadi kemudian, supaya sanksi pidana yang dijatuhkan tersebut dapat imbang dengan tindakan dan konsekuensi yang ditimbulkan yaitu sampai mengakibatkan matinya seseorang. Apabila tindakan yang dilakukan oleh terdakwa tidak sampai mengakibatkan matinya orang lain, maka sebaiknya dihindarkan untuk menjatuhkan pidana mati kepada terdakwa terkecuali bagi perbuatan yang sangat berbahaya bagi kelangsungan hidup manusia pada saat sekarang maupun di masa nanti. Sehingga, konsep pemasyarakatan dalam hal tersebut dapat diwujudkan sebagai bentuk proses pembinaan untuk narapidana yang bertujuan untuk mengadakan perubahan-perubahan

\footnotetext{
14 I Nyoman Ngurah Suwarnatha, Kebijakan Hukum Pemidanaan Anak Dalam Konsep RUU KUHP 2010, Jurnal Advokasi Vol.1, No. 1, Edisi September 2011, Fakultas Hukum Universitas Mahasaraswati, Denpasar, hlm.3.
} 
yang mengarah pada kehidupan yang lebih baik lagi. Dengan menyelenggarakan sistem pemasyarakatan agar narapidana bisa memperbaiki diri dan tidak mengulangi perbuatannya kembali.

Identifikasi kebijakan konsep mengenai pidana mati dalam RUU KUHP adalah sebagai berikut :

1. Tetap dipertahankan secara eksepsional dan tidak bisa menjatuhkannya terhadap orang dibawah umur.

2. Pidana alternatif yang digunakan dengan penuh kehati-hatian dan sebagai ultimum remidium.

3. Cara untuk menjatuhkan pidana pencabutan nyawa, yakni :

a) Sejauh mungkin dihindari memilih pidana alternatif berupa penjara seumur hidup atau maksimal dua puluh tahun (untuk dewasa) atau sepuluh tahun (untuk anak).

b) Penundaan pidana mati dengan masa percobaan 10 tahun.

c) Dalam penundaan itu, dimungkinkan adanya perubahan sanksi pencabutan nyawa menjadi penjara seumur hidup atau maksimal 20 tahun.

d) Terpidana dapat mengajukan grasi.

e) Hukuman itu baru dilaksanakan seusai pengajuan grasi tidak disetujui oleh kepala negara.

f) Jika grasi tidak diterima dan penundaan penjatuhan pidana kurun waktu sepuluh tahun, maka akan dirubah menjadi penjara semur hidup.

Adapun perbuatan yang dapat dijatuhi pidana penghilangan hidup seseorang seperti yang diuraikan diatas adalah melakukan tindakkejahatan secara tidak wajar, perbuatan tersebut dilakukan dengan cara yang sangat kejam dan sadis, misalnya saja pembunahan disertai dengan mutilasi ini. Penjatuhan pidana mati bagi pelaku pembunuhan disertai mutilasi wajib memberikan perhatian pada tujuan pemidananaan sebagai suatu bentuk untuk melindungi kepentingan pribadi maupun umum yang didasarkan oleh dasar negara kita.

Khususnya penjatuhan pidana mati terhadap kasus pembunuhan berencana disertai dengan mutilasi sebagai dasar pemberatan haruslah diberikan pedoman pemidanaan bagi hakim, karena dalam KUHP sekarang sama sekali belum diatur hal tersebut. Padahal hakim disini diharuskan untuk memberikan dasar pertimbangan dalam setiap putusannya, sesuai ketentuan Peraturan Perundang-undangan No.48 Tahun 2009 Pasal 14 ayat (2). Pertimbangan Hakim sebelum menjatuhkan putusan pidana harus sesuai dengan rasa keadilan, kemanfaatan dan kepastian.

Sehingga, secara khusus sangat perlu dilakukan formulasi pedoman pelaksanaan pidana sebagai hal yang memberatkan dalam putusan pertimbangan hakim perihal penjatuhan sanksi pidana mati terhadap motif mutilasi tindak pidana pembunuhan berencana untuk menghilangkan jejak korban dalam RUU KUHP Nasional Indonesia terkait dengan pidana mati sendiri. Serta terkait dengan pola pemidanaan menurut Wirjono Prodjodikoro, "pola pemidanaan dapat dilakukan dengan cara menggolongkan tindak pidana dengan melihat kepentingan 
yang dilindungi yang meliputi kepentingan individu dan kepentingan masyarakat". ${ }^{15}$ Adapun pola pemidanaan menentukan berat ringannya sanksi pidana yang akan diancamkan sesuai dengan kualifikasi sanksi pidana

Adapun dalam hal pedoman pemidanaan, juga telah tercantum dalam Pasal 55 RUU KUHP. Ringannya perbuatan keadaan pribadi pembuat atau keadaan pada waktu dilakukan perbuatan atau yang terjadi kemudian dapat dijadikan dasar pertimbangan untuk tidak menjatuhkan pidana atau mengenakan tindakan dengan mempertimbangkan segi keadilan dan kemanusiaan.

Pedoman pemidanaan dalam RUU KUHP sudah diaplikasikan, dan untuk selanjutnya agar tidak terjadi kekosongan norma, dikarenakan dalam peraturan hukum pidana nasional kita tidak mencantumkan hal ini, maka untuk segera peraturan yang dicita-citakan ini dijadikan kodifikasi hukum Indonesia agar sesuai dengan keinginan budaya bangsa Indonesia.

\section{Penutup}

\section{1 Simpulan}

1. Keberadaan pidana mati terhadap tindak pidana pembunuhan berencana masih tetap dipertahankan dan berlaku sampai saat ini di Indonesia, sebagaimana telah sesuai dengan ketentuan Pasal 340 KUHP.

2. Kebijakanhukum pidana terkaitdengan pidana mati masih tetap dipertahankan

15 Suhariyono, Perumusan Sanksi Pidana Dalam Pembentukan Peraturan Perundang-Undangan, Jurnal Hukum: Vol XVII No.1 Edisi Januari, Fakultas Hukum Universitas Pancasila, Jakarta, hlm.25. dan diatur dalam ketentuan Pasal 66 RUU KUHP, walaupun bukan merupakan jenis pidana pokok tetapi sebagai pidana alternatif. Terkait dengan tindak pidana pembunuhan berencana yang tercantum dalam Pasal 581 RUU KUHP, masih juga mencantumkan pidana mati namun memang dapat diancamkan secara alternatif dengan jenis pidana lainnya, seperti pidana penjara seumur hidup atau pidana penjara paling singkat lima tahun dan paling lama 20 tahun. Dalam hal ini, RUU KUHP tidak mencantumkan mutilasi secara khusus sebagai alasan yang memberatkan pidana, akan tetapi apabila dilihat dari ketentuan Pasal 55 ayat (1) RUU KUHP, maka mutilasi dapat merupakan suatu motif dan tujuan melakukan tindak pidana (huruf b); cara melakukan tindak pidana (huruf e); serta sikap dan tindakan pembuat sesudah melakukan tindak pidana (huruf f).

\subsection{Saran}

1. Pemerintah harus tetap mempertahankan ancaman pidana mati dengan membuat aturan yang secara jelas dan tegas mengenai pedoman pemidanaan dalam menjatuhkan putusan pidana mati terhadap tindak pidana pembunuhan berencana. Hukum di negara Indonesia masih tetap mempertahankan pidana mati, sehingga hakim dapat menentukan sikap dalam memutuskan perkara yang berkaitan dengan tindak pidana pembunuhan berencana. 
2. Kebutuhan KUHP Nasional sudah sangat mendesak, pemerintah sudah sewajarnya, segera mengundangkan hal tersebut. Sehingga ketentuan yang terdapat dalam Pasal 55 RUU KUHP dapat dijadikan sebagai pedoman pemidanaan bagi hakim dalam penjatuhan putusan pidana terhadap tindak pembunuhan berencana disertai mutilasi sebagai hal yang memberatkan, sesuai dengan tujuan hukum, yaitu terciptanya kepastian hukum, kemanfaatan hukum, dan keadilan hukum.

\section{Daftar Pustaka}

\section{Buku :}

Ali, Achmad 2010, Menguak Realitas Hukum: Rampai Kolom \& Artikel Pilihan Dalam Bidang Hukum, Prenada Media Group, Jakarta. Amiruddin dan H. Zainal Asikin, 2004, Pengantar Metode Penelitian Hukum, PT Raja Grafindo Persada, Jakarta.

Ashshofa, Burhan, 2001, Metode Penelitian Hukum, Rineka Cipta, Jakarta. Chazawi, Adam 2007, Kejahatan Terhadap Tubuh dan Nyawa, PT. Raja Grafindo Persada, Jakarta.

Lamintang, P.A.F, dan Lamintang, Theo, 2013, Delik-Delik Khusus Kejahatan Terhadap Nyawa, Tubuh, dan Kesehatan, Edisi Kedua, Sinar Grafika, Jakarta.

Salim, 2013, Penerapan Teori Hukum Pada

Penelitian Tesis dan Disertasi, Raja

Grafindo Persada, Jakarta.

Sugono, Bambang, 2006, Metodelogi

Penelitian Hukum, PT. Raja Grafindo Persada, Jakarta.
Ramlan, Supardi 2001, Patofisiologi, Rineka Cipta, Bandung.

\section{Jurnal :}

Bachri, Rifkiyati Pembunuhan Berencana dan Mutilasi(Kajian Putusan) No.1036 / PID /B / 2008/ PN.DPK, Jurnal Yudisial, Vol. 3, No. 2 Edisi Agustus 2010, Fakultas Hukum Universitas Pancasila, Jakarta.

Ngurah Suwarnatha, I Nyoman, Kebijakan Hukum Pemidanaan Anak Dalam Konsep RUU KUHP 2010, Jurnal Advokasi Vol.1, No. 1, Edisi September 2011, Fakultas Hukum Universitas Mahasaraswati, Denpasar. Suhariyono, Perumusan Sanksi Pidana Dalam Pembentukan Peraturan Perundang Undangan,Jurnal Hukum: Vol XVII No.1 Edisi Januari 2012, Fakultas Hukum Universitas Wijaya Kusuma, Surabaya.

\section{Internet :}

Firmansyah, Arief, 2007, Penerapan Pidana Mati Dalam Hukum Pidana Nasional Dan Perlindungan Hak Azasi Manusia, Jurnal Hukum: Vol IX. No.3, tersedia di website http://hukum. unisba.ac.id/syiarhukum/index.php/ jurnal/item/87-penerapan-pidanamati-dalam-hukum-pidana-nasionaldan-perlindungan-hak-asazi-manusia, diakses 10 Februari 2015.

\section{Peraturan Perundang-Undangan :}

Undang-Undang Dasar Negara Republik Indonesia Tahun 1945

Kitab Undang-undang Hukum Pidana (KUHP) 
Undang-undang No. 8 Tahun 1981 Tentang Kitab Undang-undang Hukum Acara Pidana (KUHAP)

Undang-undang No.12 Tahun 1995 Tentang Pemasyarakatan

Undang-undang No.39 Tahun 1999 Tentang Hak Asasi Manusia

Undang-Undang No.12 Tahun 2005 tentang Pengesahan Konvensi Internasional Hak-Hak Sipil dan Politik (ICCPR)

Deklarasi Universal Hak-Hak Asasi Manusia (DUHAM)

Rancangan KUHP 2013. 